\title{
An Investigation of School Improvement Recognition Towards Madrasah's Teachers in East Java
}

\author{
Ali Mustofa ${ }^{1}$, Mukhlas Samani' ${ }^{2}$, Soedjarwo ${ }^{3}$ \\ 1,2,3 Universitas Negeri Surabaya, Surabaya, Indonesia \\ 1 UIN Sunan Ampel Surabaya, Surbaaya, Indonesia
}

\begin{tabular}{|c|c|}
\hline (A) Check for updates open $\widehat{O}_{\text {access }}$ (c) (i) (2) & DOI : https://doi.org/10.46245/ijorer.v2i3.112 \\
\hline Sections Info & ABSTRACT \\
\hline Article history: & This study aimed at investigating the relationship between school \\
\hline Submitted: April 9, 2021 & improvement and demographic variables such as age, gender, length of \\
\hline Final Revised: April 23, 2021 & teaching, teacher's employment status and educational background. \\
\hline Accepted: April 29, 2021 & Involving 400 participants of Madrasah Tsanawiyah's (Islamic junior high \\
\hline Published Online: May 31, 2021 & schools) teachers in East Java and using school improvement scale, this study \\
\hline Keywords: & found that the higher teacher's educational qualification is, the better the \\
\hline Demographic Variables & performance shown, which subsequently had consequences for school \\
\hline Improvement Recognition & improvement in assisting students' achievement. Likewise, the length of \\
\hline Investigation & teaching and teachers' employment status were found bringing influence on \\
\hline Madrasah's Teacher & school improvement although their correlation directions vary. Meanwhile, \\
\hline 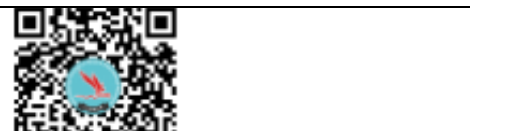 & $\begin{array}{l}\text { gender and age are not related to school improvement. This study suggested } \\
\text { teachers' professional development to enable assistance for students' success } \\
\text { and eventually lead to school improvement. }\end{array}$ \\
\hline
\end{tabular}

\section{INTRODUCTION}

School improvement is a part of the agenda of school reformation (Dyke, 2020; Mogren et al., 2019) which was established in 1980 motivated by the failure of schools to produce qualified graduates (Dyke, 2020). During 40 years since its establishment, school improvement has been widely investigated for its roles in school systems and processes (Dyke, 2020), principal policies (Klein \& Schwanenberg, 2020; Murphy, 2014), and classroom teaching and learning (Meyer et al., 2018) to produce excellent students (Dyke, 2020). Furthermore, currently school improvement has been used to improve schools' quality in increasing graduates' academic achievement (Aladjem et al., 2010; Bishara, 2017; Masters, 2016) and student welfare (Graham et al., 2014; Masters, 2016).

School improvement simply means making schools as a better place for learning (Masters, 2016) which includes improvement in 9 domains. They are an explicit improvement plan, (Department of Education, 2019; Guluguba State School, 2016; Masters, 2016), data analysis and discussion (Hough et al., 2018; Masters, 2016; North Central Regional Educational Laboratory (NCREL), 2004; Schildkamp, 2019), culture(s) that support learning process (Glusac et al., 2015; Masters, 2016; Narayan, 2016), targeted use of school resources (Bellei et al., 2016; Masters, 2016), expert teaching teams (Masters, 2016; Mincu, 2013), systematic curricula delivery (Adelman \& Taylor, 2019; Maier et al., 2017; Masters, 2016), differentiated teaching and learning (Aladjem et al., 2010; Department of Education, 2020; Masters, 2016), pedagogical practice (Masters, 2016; Vieluf et al., 2012) and school-community partnerships (Jung \& Sheldon, 2020; Masters, 2016). All the aforementioned domains are features that schools need to deal with during the school improvement process. Nevertheless, schools are flexible to prioritize its improvement in those domains based on the expected and set goals (Masters, 2016). 
In addition, the changes as the result of school improvement should not only reflect the implementation of policy, but also adapt the transformation of better learning process and environment that brings significant impact on teachers, students as well the school itself (Nair, 2019). Due to the substantial impact of school improvement on education, Indonesian government set it as a part of important agenda of national education system since the enactment of Law number 20 of 2003. Article 50 in paragraph 3 of that Law states that the government or local government should regulate at least one unit at all level of education to be internationally standardized education unit (Jaedun, 2009). That regulation is also strengthened by Government Regulation issue number 19 of 2005 concerning National education standard. The Regulation explains schools including madrasah (Alawiyah, 2014; Solahudin, 2018) should conduct school improvement to upgrade graduates' achievement (Saifulloh et al., 2012).

Madrasah is born from indigenous local wisdom of Indonesia that provide learning systems. As formal education, Madrasah is not only a home for religious educationoriented but also for general studies(Suhirman, 2015; Tahir, 2017). After attending madrasah, the graduates are expected to have a solid foundation of religious teaching as well as to excel in general subjects such as physic, biology and the likes. (Buchari \& Saleh, 2017; Murtadho, 2012; Rusydi, 2014). However, some studies show the quality of madrasah's graduates are relatively lower than those of secular education (Huda, 2016; Irwandi, 2017; Yahya, 2015). It then implies the low quality of education in madrasah (Huda, 2016; Yahya, 2015). Moreover, the majority (85\%) of madrasah in Indonesia are private schools (Kemenag RI, 2014; Yahya, 2015) which adds to more problems for school development such as lack of funding (Irwandi, 2017; Yahya, 2015), lack of teachers, teachers' low competence (Huda, 2016), inadequate school resources and facilities (Huda, 2016; Yahya, 2015), and poor school management systems (Irwandi, 2017).

The above unfavorable conditions urge the implementation of school improvement to upgrade either the quality of madrasah or its attendants (Hasbi, 2013; M Maskur, 2017; Mahdi, 2016) particularly the improvement in madrasah tsanawiyah (MTs, junior high school level) (Dewi, 2019; Wahyuni, 2015; Wigati, 2019). MTs is a part of 9 years compulsory basic education (Kementerian Pendidikan dan Kebudayaan, 2017) which plays great roles in determining the quality of secondary high schools (Hendra, 2011; Oktiani, 2019), such as general high schools, madrasah aliyah (MA), vocational high school, vocational madrasah aliyah and other equal school levels (Kementerian Pendidikan dan Kebudayaan, 2017). The significant role of MTs implies the needs of high education quality. In Indonesia the quality of MTs is discriminated by level of accreditation such as $\mathrm{A}, \mathrm{B}$, and $\mathrm{C}$ (the order of Alphabets determines the higher level of accreditation). However, most MTs $(9,2 \% / 5.232)$ fall into B category and others belong to $C(26,6 \%$ /3.536), while only 9,2\% (1.219) MTs are A level and the rest are not accredited $(24,9 \% / 3.305)$ (Kemenag RI, 2014). The low proportion of A level- MTs shows the urgency of improving the education quality at respected level (Kemenag RI, 2014; Rukiyah, 2016) through the school improvement plan (Murtadho, 2012; Taufik, 2014).

During the process of school improvement, teachers' recognition plays significant roles in assessing to what extent the school have made any changes Reaves \& Cozzens, (2018); Mitchell \& Shoho, 2017; Scott et al., 2014). The results of teachers' recognition of goals, process, and supports will serve as considerations for evaluating the improvement made (Scott et al., 2014). The following are some studies show the contribution of 
teachers' recognition of school improvement on students' success (Mitchell \& Shoho, 2017).

Some previous related studies report that the ability to accept any changes in the schools is closely related to teachers' demography factor (Lawrence \& Tar, 2018; Tate, 2019; Topchyan \& Woehler, 2020), such as gender (Thien \& Adams, 2019; Topchyan \& Woehler, 2020; Watson et al., 2019), age (Lawrence \& Tar, 2018; Millanti, 2020; Tate, 2019), the length of teaching experience (Chiong et al., 2017; Gore et al., 2017; Rajesh Shah \& Udgaonkar, 2018), teacher employment status (Angreranti \& Malihah, 2018; Suryana \& Wahab, 2020; Topchyan \& Woehler, 2020) and teachers' educational background (Mincu, 2015). Experienced and skilled teachers can relatively bring positive impact on school improvement due to professional and high performance.

Likewise, age also among demographic factors that influence teachers' teaching performance which concurrently impact school improvement. On one hand, as the aged advanced, teachers appear to be less motivated due some factors (Millanti, 2020; Rajesh Shah \& Udgaonkar, 2018) such as boredom because of teaching constantly the same content and with the same method over period of times (Rajesh Shah \& Udgaonkar, 2018) and mental and physic health that are deteriorating (Millanti, 2020), while younger teachers are considered to be more adaptive towards teaching and learning development (Lawrence \& Tar, 2018; Tate, 2019). On the other hand, age is considered is a considerable asset to learning and teaching process (Chiong et al., 2017; Rajesh Shah \& Udgaonkar, 2018), because of a lot of experience they have been through. Furthermore, successful tenure and trainings they have attended allow teachers for potential promotion (Rajesh Shah \& Udgaonkar, 2018).

Meanwhile, another demographic factors such as teacher employment status also determine teachers' performance and school improvement respectively (Angreranti \& Malihah, 2018; Suryana \& Wahab, 2020; Topchyan \& Woehler, 2020). In Indonesia, teacher employment status is classified into three categories, pegawai negeri sipil (PNS, teachers employed by the government), private teachers or non-PNS. Researches show that PNS-teachers appear to be more professional and motivated than non-PNS teachers are (Nastiti, 2016; Supriyono, 2017). The fact that they are always being assessed to be eligible for promotions (Supriyono, 2017), and benefits (salary and additional allowance) urge PNS-teacher to keep motivated and keep improving their pedagogical performance (Aisyah, 2017; Supriyono, 2017). Nevertheless, non-PNS- teachers also can maximize their performance (Agung et al., 2020; Nurbaya et al., 2020) when they are given the same opportunities to attend and receive competency trainings (Rahmawati, 2019) and allowances as their counterparts do (Rahmawati, 2019; Wantini, 2019).

Unlike the other aforementioned demographic factors, results of studies on whether gender influence teaching performance hence school improvement vary. Some studies show that gender influence school improvement, in the sense that female teachers have more higher achievement that male teachers do in increasing graduates' quality (Thien \& Adams, 2019; Topchyan \& Woehler, 2020; Watson et al., 2019). Female teachers were found to be more committed to change (Thien \& Adams, 2019), more innovative in the use of instructional media that support school improvement (Wuryaningsih et al., 2020), and better able to improve student achievement (Gong et al., 2018; Lee et al., 2019) through the creation of positive emotions in students in the learning process (Gong et al., 2018). However, other studies found no difference in gender to increase students' achievement (Rajesh Shah \& Udgaonkar, 2018). In other words, both male and female 
teachers have equal opportunity to assist students' to succussed. Therefore, the future researches on gender roles on school improvements are needed.

Based on the described explanation above, it is important to conduct a school improvement recognition study on madrasah teachers. This current study aims at revealing teacher recognition of school improvement based on teachers' demographic factors such as gender, age, length of teaching experiences and teacher employment status as well as the status of the madrasahs (private or public schools) themselves.

\section{RESEARCH METHOD}

\section{Types and Research Approaches}

Quantitative research with a correlational strategy was used to measure the relationship between two variables, namely independent and dependent variables chosen in this study (Dernowska, 2017; Hodge, 2020). Correlational quantitative research was conducted as an analytical approach to predict the relationship between school improvement variable, which is a dependent variable, and independent variables such as age, gender, length of teaching, educational background, and employment status.

\section{Population and Research Subjects}

The population involved in this study were all teachers at both public madrasah tsanawiyah (MTsN) and private madrasah tsanawiyah (MTs) in East Java. However, the schools were chosen based on the criteria that they are accredited as A and B level. The technique used was stratified cluster random sampling, through 400 subjects from 40 madrasah tsanawiyah in East Java.

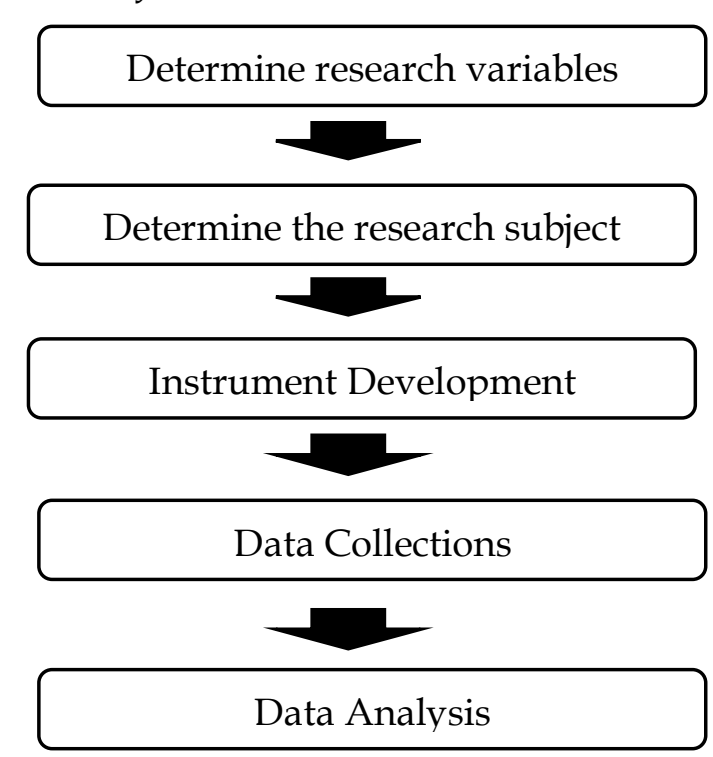

Figure 1. Flowchart of research procedures.

\section{Instruments and Procedures Research}

The instrument was the school improvement scale containing 35 statements with 5 option of answers namely almost never (HTP), rarely (J), sometimes (K), often (S), and almost always (HS). The school improvement scale was developed based on 9 aspects of Masters (2010)school improvement such as explicit improvement agenda, data analysis and discussion, culture that encourages learning, target uses of school resources, expert teaching teams, systematic curriculum delivery, differentiated learning and teaching, effective pedagogical practices, and school-community partnerships. In this scale, a 
factual data of the subjects is written, such as age, gender, length of teaching, educational background, and employment status.

The research was conducted to analyze and investigate the relationship between two variables, namely the level of teacher qualification and the performance shown, these two variables were analyzed through several aspects, both seen from job status, educational background and so on as described above. This research starts from determining the variables both independent and dependent variables, then determining research subjects involving 400 respondents, followed by developing instruments and data collection, then the data that has been obtained is analyzed based on descriptive statistics and inferential statistics and involves correlation analysis. The procedure carried out is outlined in the following flow chart in Figure 1.

\section{Data Analysis}

Descriptive statistic and inferential statistic were used to analyzed quantitative data. The former contained the distribution data including frequency, average score and standard deviation, while the letter provided a series of statistical techniques use to generalize data such as correlation (Taguchi, 2018). Meanwhile, correlation analysis was carried out using the Spearman-Rho analytical technique with the help of SPSS 16.0 for windows software to see the correlation between age, gender, length of teaching, educational background, employment status and school improvement.

\section{RESULTS AND DISCUSSION}

The statistical analysis resulted in achieving data related to teachers' demography which includes ages, gender, the latest education degree, employment status, and length of teaching. The following table depict the results.

Table 1. Demographic data of the subject teachers of madrasah tsanawiyah.

\begin{tabular}{|c|c|c|c|}
\hline & Category & Frequency & Percentage \\
\hline \multirow{3}{*}{ Gender } & Male & 176 subjects & $44 \%$ \\
\hline & Female & 224 subjects & $56 \%$ \\
\hline & Total & 400 subjects & $100 \%$ \\
\hline \multirow{3}{*}{ Age } & $18-40$ year & 193 subjects & $48 \%$ \\
\hline & $41-60$ year & 207 subjects & $52 \%$ \\
\hline & Total & 400 subjects & $100 \%$ \\
\hline \multirow{4}{*}{ The Latest Degree } & S1 (Undergraduate degree) & 327 subjects & $81 \%$ \\
\hline & S2 (Master Program) & 72 subjects & $18 \%$ \\
\hline & S3 (Doctoral Program) & 1 subjects & $1 \%$ \\
\hline & Total & 400 subjects & $100 \%$ \\
\hline \multirow{7}{*}{ Length of Teaching } & $\leq 5$ years & 70 subjects & $17 \%$ \\
\hline & $6-10$ years & 72 subjects & $18 \%$ \\
\hline & $11-15$ years & 127 subjects & $32 \%$ \\
\hline & $16-20$ years & 63 subjects & $16 \%$ \\
\hline & $21-25$ years & 46 subjects & $11 \%$ \\
\hline & $>25$ years & 22 subjects & $6 \%$ \\
\hline & Total & 400 subjects & $100 \%$ \\
\hline \multirow{3}{*}{ Employment Status } & Civil Servant (PNS) & 178 subjects & $45 \%$ \\
\hline & Non-Civil Servant (Non-PNS) & 222 subjects & $55 \%$ \\
\hline & Total & 400 subjects & $100 \%$ \\
\hline
\end{tabular}


Table 1 clearly shows the distribution of teachers' demographic data such as ages, gender, the latest education degree, employment status, and length of teaching. In terms of age, the data shows that female teachers outnumber their counterpart with $56 \%$ and $44 \%$ respectively. Meanwhile, most of the participants are aged between 41-40 years $(52 \%)$ and the rest of $48 \%$ are between 18-40 years old. Furthermore, regarding the latest degree, the data shows the majority $(81 \%)$ of the participants only hold undergraduate degree, 72 out of 400 participants did their master program and only 1 participant hold doctoral degree.

In addition, the result of teachers' demography in terms of teachers' length of teaching shows that the teachers vary in the length of teaching. Most of the teachers (127 teachers) have been teaching for 11 up to 15 years, while the teachers who have been teaching more than 25 years are only 22 teachers. Meanwhile the remaining distributions are divided into those have been teaching less that 5 years, 6 to 10 years, 16 to 20 years and 21 to 25 years, with the percentage for each category is $17 \%, 18 \%, 16 \%$ and $11 \%$ respectively. Regarding the employment status, the data shows that most of the teachers are PNS teacher $(55 \%)$, while the rest $(45 \%)$ are non- civil servant teachers.

The next analysis was used to categorize the subject based on the score of school improvement test. The subject of the current study was classified into three different classification namely high, mid, and low.

Table 2. Frequency and percentage of school improvement based on subject category.

\begin{tabular}{ccccccc}
\hline \multirow{2}{*}{ Variable } & \multicolumn{3}{c}{ Frequency } & \multicolumn{3}{c}{ Percentage } \\
\cline { 2 - 7 } & High & Mid & Low & High & Mid & Low \\
\hline School Improvement & 65 & 274 & 61 & $16 \%$ & $69 \%$ & $15 \%$ \\
\hline
\end{tabular}

Table 2 clearly shows most of the subjects (274) falls into mid category since they had mid score on school improvement test. Meanwhile 65 schools $(16 \%)$ are belong to high category and the rest of schools (61) are classified as low since they gained low score on school improvement test. In addition, correlation test using non-parametric SpearmanRho was aimed at investigating the correlation between teachers' demography features to school improvement score. The following table is the result of statistical analysis of Spearman-Rho.

Table 3. The Result of Statistical Analysis of Spearman-Rho.

\begin{tabular}{lllllll}
\hline & \multicolumn{7}{c}{ Correlation } & \\
\hline & & Gender & Age & $\begin{array}{l}\text { The latest } \\
\text { Degree }\end{array}$ & $\begin{array}{l}\text { The } \\
\text { length } \\
\text { of } \\
\text { teaching }\end{array}$ & $\begin{array}{l}\text { Employment } \\
\text { status }\end{array}$ \\
\hline \multirow{3}{*}{$\begin{array}{l}\text { School } \\
\text { Improvement }\end{array}$} & $\begin{array}{l}\text { Correlation } \\
\text { coefficient }\end{array}$ & 0.091 & 0.042 & 0.118 & -0.102 & -0.110 \\
& $\begin{array}{l}\text { Significance } \\
\mathrm{N}\end{array}$ & 0.068 & 0.404 & 0.018 & 0.041 & 0.028 \\
& 400 & 400 & 400 & 400 & 400 \\
\hline
\end{tabular}

Table 3 is the result of the Spearman-Rho statistical analysis depicting there is correlation between school improvement and some teachers' demography features. In 
details, the result shows that some teachers' demography features such as latest degree, length of teaching, and employment correlate significantly with school improvement. Firstly, for the feature of the latest degree, the data has a significant value (p) of 0.018 ( $p$ $<0.05)$ with a correlation coefficient $(\mathrm{r})$ value is $0.118(0.00-0.199)$. It means that there was significantly positive correlation between the level degree the teachers hold and the school improvement. In other words, the higher the education of the teacher is, the higher the school improvement is and vice versa. Unlike latest degree feature, the length of teaching and school improvement shown reverse correlation since $\mathrm{p}$ value was 0.041 ( $\mathrm{p}$ $<0.05)$ and $r-0.102(0.00-0.199)$. It means the longer of the teaching experience the teacher has, the lower the school improvement score is. Likewise, the shorter the teaching experience is, the higher the school improvement will be. Lastly, the variable of teacher employment status and school improvement were found to be negatively correlated as well. The $p$ of these variables was 0.028 and $r$ value was $-0.110(0.00-0.199)$. It is rightly to say that the higher the teaching status is, the lower the school improvement score will be and vice versa.

Nevertheless, the result of the Spearman-Rho statistical analysis shown that the variables of gender and age and school improvement were found to have no significant correlation. For the variable of gender, the $p$ value was $0.068(p>0.05)$ and $r$ was 0.091 . Meanwhile, for the variable of age, the $p=0.404$ and $r=0.042$.

\section{DISCUSSION}

The findings of this current study reveal that some features of teachers' demography and school improvement including length of teaching, latest educational degree and employment status were correlated significantly although the direction of the correlation vary. The correlation between variables length of teaching and school improvement were inverse. This outcome is in line with a study by (Chiong et al., 2017; Gore et al., 2017; Rajesh Shah \& Udgaonkar, 2018) that state that the longer the teaching experience teachers have, the lower they contribute to school improvement process. It is such an irony, since teachers who have been teaching for quite while are expected to have more chances and be more considerate towards schools' enhancement. Thus, having longer of teaching period does not necessarily indicate the positive and active roles in educational enhancement in the schools.

In addition, teachers' attitude towards change is considered to be blamed for this. Some teachers appear to be resistance and reluctant to changes while others are open. Based on the risk status theory, any changes can bring insecurity for some teachers (Redding \& Viano, 2018). In fact, there are two conditions where teachers are willing to do the changes. The first condition is when the changes can bring benefit to them such as strengthening their status or letting them to be promoted. The second condition is when the risks are visible while the benefit are unpredictable. Meanwhile, recognition of improvement carries risks because they tend to be time and cost consuming and may influence their employment status. Le Fevre, (2014) found that there is tendency for teacher to resist making improvement in teaching and learning when the risks are quite inevitable and they feel inadequate to carry and less adjustable toward the changes.

The results of this study in terms of correlation between teacher educational degree and school improvement support the result of previous study by Mincu (2013) that the two variables significantly positively correlated. The quality of the teachers determines the agents of school improvement. Hopkins (2013) states that characteristics of teachers 
quality can be seen from knowledge, skills, and professionality the teachers possess. Mincu (2015) states that teachers educational background gives relevant impact on students' educational attainments and eventually on schools quality. It is in line with other studies (Kusumawardani, 2017) found that teachers' educational background, teachers' trainings and students performance were found to be significantly related. Other studies (Darling-Hammond et al., 2001) adds to the fact that more experienced and certified teachers appear to have better performance than less experience teachers with lower educational degree.

Regarding to the teacher employment status, the study also found that there was significantly positive correlation between this variable and school improvement. This finding supports the previous studies found that teachers' employment status either PNS or non-PNS influence teachers' teaching performance and school improvement (Angreranti \& Malihah, 2018; Suryana \& Wahab, 2020; Topchyan \& Woehler, 2020). Aisyah (2017) and Supriyono, (2017) argue that the privilege to receive more allowance is one the reasons PNS-teachers outperform their counterparts. This prosperity is highly likely motivates PNS-teachers to keep upgrading their teaching performance and skill to assist students' achievement. Although it is not a main measurement, teachers' attitude towards school improvement depends on their perceived risk of the changes on their status (Le Fevre, 2014).

Nevertheless, the results of this study also found out that among teachers' demography features, age did not correlate with school improvement. In this regards, this outcome does not support the previous related study (Lawrence \& Tar, 2018; Tate, 2019) founded that younger teachers appear to be more adaptive to changes for achievement. The teachers in this study, regardless the age gap, have equal opportunities to contribute to school improvement. However, a study by Studi (Chiong et al., 2017) found that as the age advanced, teachers are likely considered as professional. Nevertheless, it is important to integrate fresh talented teachers to bring new ideas and innovations and with the guidance of senior teachers they can bring significant impact on school improvement (Rajesh Shah \& Udgaonkar, 2018).

Gender differences also found do not have significant correlation with school improvement. The current study found that there was no disparity between male and female teachers in the process of school improvement. This outcome coincides with the preceding related studies found that gender roles do not influence students' achievement (Rajesh Shah \& Udgaonkar, 2018). This suggest that male and female teachers share equal opportunities and responsibilities and can collaborate to improve students' academic performance and school improvement (Mora-Ruano et al., 2018) as well as are able to apply management of communication crisis during school improvement process (Alvinius et al., 2020).

\section{CONCLUSION}

The attempts to upgrade educational quality in the schools could be achieved through teachers' educational background, length of teaching, and employment status. However, school improvement does not take into account age and gender differences. Both male and female teachers regardless their age have the same opportunities to improve the quality of the schools. Furthermore, this study suggests the importance of teacher's pedagogical skill development since teachers' educational background play great role to improve both teachers' quality and school quality as well. The schools are also suggested 
to accommodate teachers' needs to secure their employment status since it influences teachers' motivation. This study also suggests more experienced and skilled teachers in teaching and learning in the sense that young teachers should improve their teaching skills and experience professionally. Considering the outcomes, this study recommends the schools to give and facilitate chances for teachers to improve professionalism and empower them with experiences and skills which enable them to make changes and bring innovations to assist students' educational success and school improvement. This research also calls for future researchers interested in similar study to focus on analyzing teachers' perceptions of the risks of making school improvements. The implication of this research to provide more detailed information about professional development of teachers in areas that are used as research subjects, used to improve the quality of education in Indonesia. If the quality of teachers can be known properly, it will make it easier to improve and innovate in teaching and learning process.

\section{REFERENCES}

Adelman, H., \& Taylor, L. (2019). Improving school improvement introduction: expanding school improvement policy: Moving from a two-to a three-component framework. UCLA.

Agung, I., Capnary, M. C., \& Perdana, N. S. (2020). Factors of effect on job expectation honorarium teachers and its impact. 7(3), 80-90.

Aisyah, N. T. (2017). Perbedaan persepsi kinerja guru pns dan non pns pada sekolah dasar negeri di desa saotengnga kabupaten sinjai. Universitas Islam Negeri Alauddin Makassar.

Aladjem, D. K., Birman, B. F., Orland, M., Harr-Robins, J., Heredia, A., Parrish, T. B., \& Ruffini, S. J. (2010). Achieving dramatic school improvement: an exploratory study. A cross-site analysis from the evaluation of comprehensive school reform program implementation and outcomes study. Office of Planning, Evaluation and Policy Development, US Department of Education.

Alawiyah, F. (2014). Islamic school education in Indonesia. Jurnal Aspirasi, 5(1), 51-58.

Alvinius, A., Deverell, E., \& Hede, S. (2020). A gender perspective on temporary organisations in crisis management. NORA - Nordic Journal of Feminist and Gender Research, 00(00), 1-14. https://doi.org/10.1080/08038740.2020.1785008

Angreranti, M., \& Malihah, N. (2018). The influence of school environment and the performance of the honorary teachers of Islamic education toward the learning achievements. MUDARRISA: Journal of Islamic Education, 9(2), 248. https:// doi.org/10.18326/mdr.v9i2.248-266

Bellei, C., Vanni, X., Valenzuela, J. P., \& Contreras, D. (2016). School improvement trajectories: an empirical typology. School Effectiveness and School Improvement, 27(3), 275-292. https://doi.org/10.1080/09243453.2015.1083038

Bishara, D. S. (2017). School effectiveness and student achievement. International Journal of Contemporary Research and Review, 08(02). https://doi.org/10.15520/ijcrr/2017/8/02/123

Buchari, A., \& Saleh, E. M. (2017). Merancang pengembangan madrasah unggul. Journal of Islamic Education Policy, 1(2), 95-112. https://doi.org/10.30984/j.v1i2.429

Chiong, C., Menzies, L., \& Parameshwaran, M. (2017). Why do long-serving teachers stay in the teaching profession? Analysing the motivations of teachers with 10 or more years' experience in England. British Educational Research Journal, 43(6), 1083-1110. https://doi.org/10.1002/berj.3302 
Department of Education. (2019). Driving an explicit improvement agenda to maximise student outcomes.

Department of Education. (2020). Whole school approach to differentiated teaching and learning Focused teaching: for identified students.

Dernowska, U. (2017). Teacher and student perceptions of school climate. Some conclusions from school culture and climate research. Journal of Modern science, 32(1), 63-82.

Dewi, Y. L. (2019). Pengaruh Iklan Web Series SPace \# “Kenapa Belum Nikah?” Terhadap Brand Awareness JD.ID. Profetik: Jurnal Komunikasi, 12(1), 141. https://doi.org/10.14421/pjk.v12i1.1556

Dyke, E. M. Van. (2020). W E M scholarworks taking a strengths-based approach to school improvement in a rural elementary school. The College of William and Mary in Virginia.

Gong, J., Lu, Y., \& Song, H. (2018). The effect of teacher gender on students' academic and noncognitive outcomes. Journal of Labor Economics, 36(3), 743-778. https://doi.org/10.1086/696203

Gore, J., Lloyd, A., Smith, M., Bowe, J., Ellis, H., \& Lubans, D. (2017). Effects of professional development on the quality of teaching: Results from a randomised controlled trial of Quality Teaching Rounds. Teaching and Teacher Education, 68, 99113. https://doi.org/10.1016/j.tate.2017.08.007

Graham, Fitzgerald, R, Powell, MA, Thomas, N, Anderson, DL, White, NE \& Simmons, C. (2014). Wellbeing in schools: Research project: Improving approaches to wellbeing in schools: what role does recognition play? Executive summary. In Centre for Children and Young People, Southern Cross University, Lismore, NS. https:// doi.org/https://doi.org/10.4226/47/58eaed4c09218

Guluguba State School. (2016). School Improvement Unit.

Hasbi. (2013). Peningkatan mutu pendidikan madrasah dalam sistem pendidikan nasional di kota palopo tahun 2011-2012. Jurnal Diskursus Islam, 1(3), 381-395.

Hendra, T. (2011). Faktor-faktor yang mempengaruhi minat siswa smp/mts tingkat akhir memilih bidang keahlian smk teknologi dan industri di kabupaten gunung kidul. Universitas Negeri Yogyakarta.

Hodge, S. R. (2020). Quantitative research. Routledge Handbook of Adapted Physical Education.

Hopkins, D. (2013). Exploding the myths of school reform. School Leadership and Management, 33(4), 304-321. https://doi.org/10.1080/13632434.2013.793493

Hough, H., Byun, E., \& Mulfinger, L. (2018). Using data for improvement: Learning from the CORE data collaborative. Policy Analysis for California Education, September.

Huda, K. (2016). Problematika madrasah dalam meningkatkan mutu pendidikan islam. Jurnal Dinamika Penelitian, 16(2), 309-336. https://doi.org/10.21274/dinamika.2016.16.2.309-336

Irwandi. (2017). Madrasah diniyah dalam konteks globalisasi (problematika dan solusinya). PIONIR Jurnal Pendidiikan, 6(1), 1-11.

Jung, S. B., \& Sheldon, S. (2020). Connecting dimensions of school leadership for partnerships with school and teacher practices of family engagement. School Community Journal, 30(1), 9-32.

Kemenag RI. (2014). Deskriptif statistik pendidikan madrasah.

Kementerian Pendidikan dan Kebudayaan. (2017). Indonesia: Educational statistics in brief 2016/2017. In Pusat data dan statistik pendidikan dan kebudayaan. MoEC (Ministry 
of Educational and Culture).

Klein, E. D., \& Schwanenberg, J. (2020). Ready to lead school improvement? Perceived professional development needs of principals in Germany. https://doi.org/10.1177/1741143220933901

Kusumawardhani, P. N. (2017). Does teacher certification program lead to better quality teachers? Evidence from Indonesia. Education Economics, 25(6), 590-618.

Lawrence, J. E., \& Tar, U. A. (2018). Factors that influence teachers' adoption and integration of ICT in teaching/learning process. Educational Media International, 55(1), 79-105. https://doi.org/10.1080/09523987.2018.1439712

Le Fevre, D. M. (2014). Barriers to implementing pedagogical change: The role of teachers' perceptions of risk. Teaching and Teacher Education, 38, 56-64. https://doi.org/10.1016/j.tate.2013.11.007

Lee, J., Rhee, D. E., \& Rudolf, R. (2019). teacher gender, student gender, and primary school achievement: Evidence from ten francophone african countries. Journal of Development Studies, 55(4), 661-679. https:/ / doi.org/10.1080/00220388.2018.1453604

M Maskur. (2017). Eksistensi dan esensi pendidikan madarsah di indonesia. Terampil : Jurnal Pendidikan dan Pembelajaran Dasar, 4(1), 1689-1699.

Mahdi. (2016). Strategi pengembangan pendidikan madrasah di Indonesia. 1-16.

Maier, A., Daniel, J., Oakes, J., \& Lam, L. (2017). Community schools as an effective school improvement strategy: A review of the evidence. Learning Policy Institute.

Masters, G. (2016). National school improvement tool. The Australian Council for Educational Research (ACER).

Masters, G. N. (2010). Teaching and learning school improvement framework.

Meyer, F., Sinnema, C., Patuawa, J., Sinnema, C., \& Patuawa, J. (2018). Novice principals setting goals for school improvement in New Zealand Novice principals setting goals for school improvement in New Zealand. School Leadership E Management, 0(0), 1-24. https:// doi.org/10.1080/13632434.2018.1473358

Millanti, D. (2020). Pengaruh usia produktif guru terhadap semangat dan disiplin mengajar di sd negeri 18 kota bengkulu. Institut Agama Islam Negeri (Iain) Bengkulu.

Mincu, M. E. (2013). Teacher quality and school improvement: What is the role of research?

Mincu, M. E. (2015). Oxford review of education teacher quality and school improvement: What is the role of research? Teacher quality and school improvement: what is the role of research ? Oxford Review of Education, 41(2), 253269. http://dx.doi.org/10.1080/03054985.2015.1023013

Mitchell, A. J., \& Shoho, A. R. (2017). High school teachers perceptions of school change and its implications for student achievement. Leadership and Policy in Schools, 16(3), 431-454. https://doi.org/10.1080/15700763.2016.1205199

Mogren, A., Gericke, N., \& Scherp, H. A. (2019). Whole school approaches to education for sustainable development: a model that links to school improvement. Environmental Education Research, 25(4), 508-531. https://doi.org/10.1080/13504622.2018.1455074

Mora-Ruano, J. G., Gebhardt, M., \& Wittmann, E. (2018). Teacher collaboration in german schools: Do gender and school type influence the frequency of collaboration among teachers? Frontiers in Education, 3(July), 1-12. https://doi.org/10.3389/feduc.2018.00055

Murphy, J. (2014). The architecture of school improvement. Journal of Educational Administration, 43(6), 563-572. 
Murtadho, A. (2012). Berbasis manajemen mutu. Jurnal Forum Tarbiyah, 10(1), 91-112.

Nair, R. S. (2019). Theory of change: A Success or a failure for school improvement, a discussion base on malaysian context. The Social Sciences, 14(1), 9-18.

Nastiti, S. M. (2016). Perbedaan kinerja guru berdasarkan status kepegawaian pns dan non pns di sma negeri se-kabupaten rembang skripsi. Universitas Negeri Semarang.

North Central Regional Educational Laboratory (NCREL). (2004). In This Issue: Using Data to Guide School Improvement. 7.

Nurbaya, S., Rasulong, I., \& R, M. N. (2020). Competence, work culture and performance of honorary teachers in makassar elementary school. European Journal of Business and Management Research, 5(2). https://doi.org/10.24018/ejbmr.2020.5.2.281

Oktiani, I. (2019). Peningkatan mutu lulusan di madrasah aliyah muhammadiyah pekuncen banyumas tesis.

Piper, B., Zuilkowski, S. S., Dubeck, M., Jepkemei, E., \& King, S. J. (2018). Identifying the essential ingredients to literacy and numeracy improvement: Teacher professional development and coaching, student textbooks, and structured teachers' guides. World Development, 106, 324-336.

Rahmawati, E. (2019). Pengaruh pembinaan kepala sekolah dan kompensasi terhadap kinerja guru non pns pada smp swasta di sektor i kabupaten indramayu. Edum Journal, 2(1), 28-42. https:// doi.org/10.31943/edumjournal.v2i1.20

Rajesh Shah, S., \& Udgaonkar, U. S. (2018). Influence of gender and age of teachers on teaching: students perspective. International Journal of Current Microbiology and Applied Sciences, 7(1), 2436-2441. https://doi.org/10.20546/ijcmas.2018.701.293

Reaves, S. J., \& Cozzens, J. A. (2018). Teacher perceptions of climate, motivation, and selfefficacy: Is there really a connection. Journal of Education and Training Studies, 6(12), 48-67.

Redding, C., \& Viano, S. L. (2018). Co-creating school innovations: Should selfdetermination be a component of school improvement? Teachers College Record, 120(11), 1-32.

Rukiyah, I. (2016). Peningkatan mutu layanan pendidikan melalui akreditasi satuan pendidikan. Ittihad, 14(25), 46-60. https:/ / doi.org/10.18592/ittihad.v14i25.863

Rusydi, I. (2014). Optimisme pendidikan madrasah di Indonesia (Prospek Dan Tantangan). Risalah; Jurnal Pendidikan dan Studi Islam, 1(1), 7-19.

Saifulloh, M., Muhibbin, Z., \& Hermanto, H. (2012). Strategi peningkatan mutu pendidikan di sekolah. Jurnal Sosial Humaniora, 5(2), 206-218. https://doi.org/10.12962/j24433527.v5i2.619

Schildkamp, K. (2019). Data-based decision-making for school improvement: Research insights and gaps. Educational Research, 61(3), 257-273. https://doi.org/10.1080/00131881.2019.1625716

Scott, C., Parsley, D., \& Fantz, T. (2014). Connections between Teacher Perceptions of School Effectiveness and Student Outcomes in Idaho's Low-Achieving Schools. Summary. REL 2014-012. Regional Educational Laboratory Northwest, March, 1-40.

Solahudin. (2018). Peran strategis madrasah swasta di Indonesia. Jurnal Kependidikan, 6(1), 91-106. https:// doi.org/10.24090/jk.v6i1.1717

Suhirman. (2015). Peningkatan mutu madrasah berkelanjutan (sustainability) berbasis Kinerja Guru. BIOTA: Jurnal Tadris IPA Biologi FITK IAIN Mataram, 7(2), 157-172.

Supriyono, A. (2017). Pengaruh kompetensi pedagogik, profesional, dan motivasi kerja terhadap kinerja guru sekolah dasar. Jurnal Pendidikan, 18(2), 1-12. 
https://doi.org/10.33830/jp.v18i2.269.2017

Suryana, N., \& Wahab, A. A. (2020). The effect of work discipline and organizational culture on service quality in teaching and learning process (case study of civil servant teachers in $\begin{array}{llll}\text { kuningan } & \text { area). } & \text { 2019), (Icream }\end{array}$ https://doi.org/10.2991/assehr.k.200130.157

Taguchi, N. (2018). Description and explanation of pragmatic development: Quantitative, qualitative, and mixed methods research. System, 75, 23-32.

Tahir, A. W. (2017). Implementasi manajemen berbasis madrasah dalam peningkatan mutu. Lentera Pendidikan: Jurnal Ilmu Tarbiyah Dan Keguruan, 20(2), 240-249. https://doi.org/10.24252/lp.2017v20n2i9

Tate, L. M. (2019). Relating millennial teachers' age to frequency and variety of instructional technology use in elementary math. Liberty University.

Taufik, O. A. (2014). Determinasi madrasah efektif. Jurnal Administrasi Pendidikan UPI, 21(2), 38-50. https:// doi.org/10.17509/jap.v21i2.6674

Thien, L. M., \& Adams, D. (2019). Distributed leadership and teachers' affective commitment to change in Malaysian primary schools: the contextual influence of gender and teaching experience. Educational Studies, 00(00), 1-21. https://doi.org/10.1080/03055698.2019.1680349

Topchyan, R., \& Woehler, C. (2020). Do teacher status, gender, and years of teaching experience impact job satisfaction and work engagement? Education and Urban Society, 1-27. https://doi.org/10.1177/0013124520926161

Vieluf, S., Kaplan, D., Klieme, E., \& Bayer, S. (2012). Teaching Practices and Pedagogical Innovation. In Kuram ve Uygulamada Eğitim Bilimleri (Vol. 9). https://doi.org/10.1787/9789264123540-en

Wahyuni, L. T. (2015). Perencanaan strategik madrasah dalam meningkatkan mutu pendidikan (studi multisitus di mts negeri jabung blitar dan mts negeri gandusari blitar). Universitas Islam Negeri Maulana Malik Ibrahim Malang.

Wantini, A. A. (2019). the Validity test of depression screening instrument in $\begin{array}{lllll}\text { adolescences. Jurnal Berkala Epidemiologi, } & 7(2), & 155 .\end{array}$ https://doi.org/10.20473/jbe.v7i22019.155-162

Watson, P. W. S. J., Rubie-Davies, C. M., Meissel, K., Peterson, E. R., Flint, A., Garrett, L., $\&$ McDonald, L. (2019). Teacher gender, and expectation of reading achievement in New Zealand elementary school students: essentially a barrier? Gender and Education, 31(8), 1000-1019. https://doi.org/10.1080/09540253.2017.1410108

Wigati, A. (2019). Implementasi manajemen mutu madrasah di madrasah tsanawiyah (mts) negeri 2 bandar lampung. Universitas Islam Negeri Raden Intan Lampung.

Wuryaningsih, Darwin, M., Susilastuti, D. H., \& Pierewan, A. C. (2020). Performance in innovative teacher professional development (TPD) in Indonesia: Does gender metter? Innovative Teaching and Learning Methods in Educational Systems, 231-236.

Yahya, F. A. (2015). Problem manajemen pesantren, sekolah dan madrasah: problem mutu dan kualitas input-proses-output. El-Tarbawi, 8(1), 93-109. https://doi.org/10.20885/tarbawi.vol8.iss1.art6 


\footnotetext{
* Ali Mustofa (Corresponding Author)

Doctoral Program of Educational Management, Universitas Negeri Surabaya, Indonesia

Jl. Raya Kampus Unesa, Lidah Wetan, Kec. Lakarsantri, Surabaya, Indonesia

Lecturer in UIN Sunan Ampel Surabaya, Indonesia

Email: alimustofa16070976006@mhs.unesa.ac.id
}

\section{Prof. Dr. Mukhlas Samani}

Lecturer at Postgraduate Program of State Universitas of Surabaya

Jl. Raya Kampus Unesa, Lidah Wetan, Kec. Lakarsantri, Surabaya, Indonesia

Email: msamani@unesa.ac.id

\section{Dr. Soedjarwo}

Lecturer at Postgraduate Program of State Universitas of Surabaya

Jl. Raya Kampus Unesa, Lidah Wetan, Kec. Lakarsantri, Surabaya, Indonesia

Email: soedjarwo@unesa.ac.id 